\title{
Strategic Management in Quality Improvement at State Madrasah
}

\author{
Mustapidי, Syafaruddin², Candra Wijaya3 \\ DOI: $10.35445 /$ alishlah.v13i3.958
}

\section{Article Info}

Keywords:

Strategic Management; Quality Improvement; State Madrasah

Kata kunci:

Manajemem Strategi; Peningkatan Mutu; Madrasah Negeri

\begin{abstract}
This study aims to analyze strategic planning, policy implementation and evaluation of quality improvement programs at a State Madrasah Aliyah Medan. This study uses a qualitative approach with data collection techniques through interviews, observation and documentation. While strengthening the validity of the data from research findings, the use of data validity standards based on Lincoln \& Guba consists of credibility, transferability, dependability, and confirmability. The results of this study indicate that; 1) strategic planning in quality improvement is carried out by deliberation and teamwork to formulate the madrasa's vision and mission, analysis of the internal environment of the resources owned by the madrasa and the external environment of the madrasa environment both geographically, socio-culturally and economically, analysis of strategy selection and the key to success appropriate, and strategy selection; 2) Implementation of madrasa policies in quality improvement is carried out by implementing education quality improvement programs and adopting policies to carry out continuous process improvements, establishing quality assurance and quality standards for quality improvement, creating a madrasa culture or culture, making organizational changes and maintaining good relations with stakeholders both central government, regional and community; and 3) Evaluation of the quality improvement program is carried out through monitoring all the results of planning and implementation, measuring the performance of individuals and madrasah institutions, compiling reports on the implementation of activities and taking corrective steps.
\end{abstract}

\begin{abstract}
Abstrak
Penelitian ini bertujuan untuk menganalisis perencanaan strategi, implementasi kebijakan dan evaluasi program peningkatan mutu di salah satu Madrasah Aliyah Negeri Medan. Penelitian ini menggunakan pendekatan kualitatif dengan teknik pengumpulan data melalui wawancara, observasi dan dokumentasi, sedangkan untuk memperkuat kesahihan data hasil temuan penelitian, maka penggunaan standar keabsahan data berdasarkan Lincoln \& Guba, yang terdiri dari creadibility, tranferability, dependability dan comfirmability. Hasil penelitian ini menunjukkan bahwa; 1) perencanaan strategik dalam peningkatan mutu dilaksanakan secara musyawarah dan kerjasama tim untuk merumuskan visi dan misi madrasah, analisis lingkungan internal terhadap sumber daya yang dimiliki madrasah serta lingkungan eksternal terhadap lingkungan madrasah baik geografis, sosio kultural maupun ekonomi, analisa pemilihan strategi dan kunci keberhasilan
\end{abstract}

${ }^{1}$ Universitas Islam Negeri Sumatera Utara Medan, Sumatera Utara, Indonesia Email: sirariefaulia@gmail.com ${ }^{2}$ Universitas Islam Negeri Sumatera Utara Medan, Sumatera Utara, Indonesia Email: syafar_mpd@yahoo.co.id 3Universitas Islam Negeri Sumatera Utara Medan, Sumatera Utara, Indonesia Email: candrawijaya@uinsu.ac.id 
secara tepat, dan pemilihan strategi; 2) Implementasi kebijakan madrasah dalam peningkatan mutu dilaksanakan dengan menerapkan programprogram peningkatan mutu pendidikan dan mengambil kebijakan melakukan perbaikan proses secara berkesinambungan, menetapkan jaminan mutu dan standar mutu peningkatan mutu, menciptakan kultur atau budaya madrasah, melakukan perubahan organisasi dan mempertahankan hubungan yang baik dengan stakeholders baik pemerintah pusat, daerah maupun masyarakat; dan 3) Evaluasi program peningkatan mutu dilakukan melalui memonitor seluruh hasil dari perencanaan dan pelaksanaan, mengukur kinerja individu dan lembaga madrasah, menyusun laporan pelsksanaan kegiatan dan mengambil langkah perbaikan.

\section{INTRODUCTION}

School policymakers must provide adequate educator services and education personnel to enhance educators' competence. Additionally, Supriyadi's research discovered that it is critical to implement prerequisite policies for educators' competency development in schools, as educators are the frontline in implementing education in schools (Supriyadi, 2012). A strategy for organizing and empowering educational management services is required, beginning with planning, implementing, and supervising (Firdaus \& Ansori, 2019; Abdulraheem, et al., 2012). Dewi's research demonstrates that in addition to educators and education staff, school principals must increase their involvement in assignments, guide work discipline, and maintain consistency in their work (Dewi, 2013).

In implementing the program to accelerate the achievement of quality-oriented schools, madrasa administrators are also required to have a management strategy in the form of an adequate framework for managing the school (Mukhtar \& Prasetyo, 2020; Saleh, 2014). As stated by Irmayani et al., management is a process or framework, which involves guiding or directing a group of people towards organizational goals or real goals (Irmayani et al., 2018).

In relation to improving the quality of schools with competitiveness, education must be managed with strategic management in order to be able to choose among many good managements to produce good management to achieve quality education (Ramazani \& Jergeas, 2018; Al-Shobaki et al., 2017). Strategic Management is an art (skill), technique, and science of formulating, implementing, evaluating and monitoring various organizational, functional decisions (Simon et al., 2014; Aremu \& Oyinloye, 2014) which are always influenced by the internal and external environment, which is constantly changing so as to provide the ability for the organization to achieve its goals.

The process aspect is more important than the input and output aspects when working to improve the quality of education. It includes decision-making, program management, institutional management processes, teaching and learning processes, and monitoring and evaluation processes, with the notation that the teaching and learning processes are of the highest importance compared to other processes (Aziz et al., 2018; Wani \& Mehraj, 2014). Improving the quality of education has always been a priority for Madrasahs, both in terms of quality and quantity. This is due to the strong encouragement of school administrators to be able to compete with other schools that were first established and always compete in improving the quality of their schools. Another factor is the demands of the community who crave madrasa-based schools that are not far from where local residents live so that it does not complicate their children's education.

Implementation of strategic management is the key to the success of madrasas (Hanun, 2015; Mustiali, 2021). This is because, at the strategic formulation stage, it can anticipate the dynamics of future changes, given that an organization, both internal and external, is always changing. Through strategic planning, a strategy can be formulated so that the organization becomes a unit that is able to display high performance because a successful organization is an organization whose level of effectiveness and productivity is getting higher and higher (Fauzi, 2020; Mubarok et al., 2021; Kheroni, 2020). The goals and various targets can be achieved with satisfactory results. The 
difference with other research before, this research is conducted to find out the best practice of the strategic management in quality improvement with an insight of excellence of Madrasah Aliyah Medan.

\section{METHODS}

This research designs an approach qualitative descriptive. The researcher tries to describe the facts in accordance with the circumstances relating to Strategic Management in Quality Improvement at Madrasah Aliyah Negeri 2 Model Medan. Researchers collect quantitative and qualitative data and will be analyzed according to the characteristics of the data that researchers find in the field. The subject of this research is directed to the search data from the head of the madrasa, vice-principal and teachers. Snowball sampling started the data search from the principal as a key informant. Data were also taken from secondary sources, namely from vice-principals, teachers, employees, homeroom teachers and madrasa committees.

Data achievement will be stopped when no more data variations appear or surface or experience saturation. So the amount of information in this research is not determined with certainty depending on the level of data needed. Research data on the effectiveness of meeting national education standards was collected using observation, structured and unstructured interviews and study documentation. The data was taken from the primary source, namely the head of MAN 2 Model Medan, also known as the key informant. Data were also taken from secondary sources, namely from vice-principals, teachers, staff, homeroom teachers, and madrasa committees. The use of primary and secondary sources is to obtain a clear and comprehensive description of field data relating to the problems studied so that the data obtained will truly answer the problems studied in this study.

Qualitative data analysis is generally divided into three levels; initial level analysis, analysis during field data collection, and analysis after data collection. Qualitative data analysis in qualitative research is to reduce data because qualitative data collected must be in-depth and sufficient according to the focus and objectives of the study.

\section{FINDINGS AND DISCUSSION}

\section{Strategic planning}

The strategic planning carried out by the Head of Madrasah in terms of improving the quality in one interview opportunity obtained the following responses:

In order to realize excellence-oriented quality in this model MAN 2, the first step taken is to develop a plan which is then called a strategic plan. Starting with preparing the vision, mission and goals, analyzing the internal and external environments that are possible and can be used to support excellence, analyzing strategies that can and may be taken to realize the vision, mission, goals and programs that have been prepared and want to be realized and set indicators or the key to the success of each strategy taken and to then determine the preferred strategy to realize the predetermined goals $(\mathrm{KW})$.

The preparation of this strategic plan involves all the supporting elements and leaders in MAN 2 This model, be it the head of the madrasa, deputy head of the madrasa, head of administration, homeroom, or madrasa committee which takes place in deliberation and is led by a team leader who is determined and in a decree. Madrasah principal (RSH).

Based on the description above, it can be stated that the strategic planning carried out by the Head of Madrasah in terms of improving the quality of insightful excellence in is carried out through the stages of vision and mission formulation, analysis of the external and internal environment, analysis of strategy choices and determining the key to success and strategy selection. This planning is based on the results of the study of the attendance list document involving all elements of madrasa organizers by appointing a team leader and taking place through deliberation. 
In-depth interviews related to the implementation of this strategic planning stage received the following responses:

\section{a. Formulation of Vision and Mission}

The vision and mission of MAN 2 Model Medan are realized through a long formulation process based on the results of the unification of thoughts from all stakeholders in a deliberation involving school principals, deputy principals, heads of administration, homeroom teachers and madrasa committees. This is as expressed by the deputy head of the madrasa in the field of the curriculum in an interview as follows:

The vision and mission of MAN 2 Model Medan were realized through a long formulation process based on the results of the unification of thoughts from all stakeholders in a deliberation involving the head of administration, homeroom teacher and madrasa committee and led by the team leader. (WKM-1).

The formulation of the vision and mission, of course, also considers the position, carrying capacity, analysis of community needs and expectations of this MAN 2 model. As it is known that MAN 2 is one of the reference madrasas that prioritizes quality and excellence, on this basis, also we have compiled a vision and mission that is prepared in the hope of meeting those demands. (KM)

Furthermore, the researchers tried to present data from interviews about the vision and mission of MAN 2 Model Medan as follows:

The vision and mission of MAN 2 Model is not permanent from time to time but changes as the community demands. Currently, this vision and mission is directed at the formation of superior Islamic characters in achievements with a global perspective, love for the environment and the homeland. (WKM-2).

The results of the interview with the deputy head of the madrasa in the field of facilities and infrastructure above are strengthened by the interview with the head of administration who stated that:

The vision and mission that we have formulated together become a common direction and spirit in doing our best in carrying out our respective duties and responsibilities to improve the quality of madrasas so that in the future it is expected to produce graduates with insightful excellence in the form of good morals and high achievers. (KTU).

Furthermore, the explanation of the vision and mission was explicitly conveyed by several homeroom teachers in one interview as follows:

The vision and mission of the madrasa is what has been described and aspired to with the aim of realizing a quality and superior madrasa. The highest hope lies in this vision, mission and goals which form graduates who have good character, high achievers and global insight, love for resilience and the madrasa environment as something that makes the needs of madrasa residents, including students and the community as education customers. (WK-1, 2 and 3).

Based on the above vision and mission, the madrasah principal, deputy madrasah head, head of administration, homeroom teacher, and madrasa committee put it into work targets and programs. The results of the document study were formulated as targets and several flagship work programs of MAN 2 Model Medan. The following will present the objectives, strategic plans, targets and ways to achieve the goals and objectives for the year 2020/2021 as follows:

\section{b. Internal and External Environmental Analysis}


The second formulation carried out by the head of the madrasa related to strategic planning activities is to analyze the internal environment and external information related to environmental analysis in MAN 2 Model Medan. The results of interviews with the head of the madrasah obtained the following responses:

Strategic planning is carried out by taking into account internal and external factors that affect the achievement of objectives, including quality assurance with superior insight, this effort is carried out to make it easier to formulate the chosen strategic formulation. (KM).

Furthermore, the results of interviews with the deputy head of the madrasa in the field of curriculum and the deputy head of the madrasa in the field of facilities and infrastructure also conveyed the following:

Analysis of the internal and external environment has been carried out when preparing the Strategic Plan and Madrasah Self-Evaluation. This analysis needs to be carried out in order to ensure that the goals to be achieved are relevant to the carrying capacity of the madrasa, we know that MAN 2 Model Medan is a model madrasa that is expected to be able to produce graduates who excel in their fields as programs developed in the natural sciences, social sciences, religious sciences and religious studies. This internal analysis usually involves an analysis of strengths, weaknesses, opportunities and challenges, thank God, we do this even though it is possible that it is not yet complete. (WKM-1 and WKM-2).

Searching the Madrasah Self Evaluation documentation, researchers found data from the analysis of the internal and external environment of MAN 2 Model Medan which are summarized in Table 10 as follows:

Table 1. Internal Analysis in Self-Evaluation

\section{Strengths}

1. Excellent madrasa management and ensuring the achievement of the vision and mission.

2. The quality of professional and competent teaching staff and education personnel based on the field of program management such as natural sciences, social sciences, religious studies or linguistics.

3. A conducive madrasa atmosphere with indicators of maintaining good relations between staff educators, education staff, committees and students.

4. The economic ability of the students' parents is relatively sufficient.

5. Providing dominant religious material and educating participants with morals and examples that will become the basis for building student character.

6. Strategic location of madrasas from access and availability of supporting facilities.

7. Graduates who are widely used by the best PTNPTKIN in Indonesia follows:

While the results of environmental analysis based on external MAN 2 Model Medan are as 


\section{Table 2. External Analysis in Self-Evaluation of Madrasah MAN 2 Model Medan}

\section{Opportunities}

1. The high interest of the community/parents to send their children to MAN 2 Model Medan from year to year.

2. MAN 2 Model Medan is the only Madrasah at the Aliyah level that was asked to serve as a model and until now it has become a reference for madrasas at the same level in North Sumatra.

3. Availability of facilities and infrastructure to support learning and excellent character building as well as the availability of qualified teachers S1, S2 and S3 according to the field of science.

4. Support from the central government through the ministry of religion, provincial and municipal governments, parents through committees and graduates
1. The emergence of similar madrasas and the number continues to increase from time to time with private status.

2. The influence of the environment in the association that affects students' morals makes madrasas have to work hard to make real efforts to realize their vision and mission in the form of character education for students.

Based on the results of interviews and document studies above, it can be seen that both internal and external environmental analyzes have used SWOT (strengths, weaknesses, opportunities and threats) analyzes from outside the system. The SWOT analysis in question is part of the contextualization of internal and external analysis for MAN 2 Model Medan in seeing the opportunities and challenges of madrasas.

The two tables above show that although MAN 2 Model Medan is rated "model" and becomes a reference for other madrasas, both in terms of management, academic and non-academic, based on their self-evaluation, it shows that there are internal problems faced including the high demands of parents on competencies, achievements and changes in the character or character of students and graduates as well as the limited area of development at location 1 so that it requires carrying out it at location 2 Helvetia which is less strategic in terms of improving the appearance and promotion of the existence of MAN 2 Model Medan. Some of the flagship programs, including:

1. Full Day School Program, the curriculum of this program emphasizes strengthening students' abilities in the fields of English, Arabic and Mathematics. To increase students' motivation in participating in this program, the madrasah cooperates with the State Islamic University of North Sumatra, the State University of Medan, and Arabic and English language institutions.

2. Tahfizul Qur'an program in collaboration with the Indonesian Huffazh Center Institute (HCI). In supporting this program, the madrasah cooperates with the Indonesian Huffazh Center Institute (HCI). Students who will take part in this program will be selected strictly, so students who are selected in this program will be in intensive dormitory for 6 months. Currently there are $21 \mathrm{HCI}$ alumni students who have memorized the Koran $30 \mathrm{Juz}$.

3. One Day One Juz program, intended to increase students' love for the Qur'an, MAN 2 Model Medan implements the One Day One Juz program. In this program students are required to complete qira'ah Al-Qur'an as much as 1 (one) juz every week, and every Saturday after completion of the learning process, students carry out khataman which is guided by the teacher who teaches at the last lesson. Furthermore, specifically for class XII students, they carried out mass completion of the Qur'an before the national exam was held.

4. The National Adiwiyata School Program is directed so that all madrasa residents, including students, have awareness and concern for the environment and the creation of comfortable and beautiful madrasas, and to realize this hope students are involved in organizing, maintaining and maintaining it. as Adiwiyata School for North Sumatra Province 2015. 


\section{c. Analysis of Strategy Options and Keys to Success}

Analysis of strategy choice and success is the strategy formulation stage carried out after the internal and external environmental analysis is carried out in MAN 2 Model Medan. This is as conveyed by the head of the madrasa, the deputy head of the madrasa, the head of administration and the homeroom teacher in one interview as follows:

Analysis of the choice of strategy and the key to success is carried out when knowing the various strengths, weaknesses, opportunities and threats of the madrasa by formulating madrasa programs and activities that are directed at efforts to improve the quality of education. This stage requires a lot of consideration, so I used to involve a lot of madrasa residents from the start, whether it was the deputy head of the madrasa, the head of administration, the homeroom teacher or the committee I appointed to a team to provide input. Until now, the implementation of the program in madrasas is running as planned, even if there are obstacles, we immediately conduct an analysis to immediately improve, regarding the superior program, alhamdulillah, it has been running as we expected. Excellence for students in class XII is held in the form of the National Examination Success program, special services for repair and enrichment as well as additional study hours. Extracurricular services are served on Saturdays. (KM)

Regarding the realization of quality that has an insight into excellence, it is really determined by various supports and factors ranging from facilities and infrastructure, extracurricular activities, educational services and collaboration with stakeholders, although I am well aware that teachers and learning quality are the main requirements. To improve the quality and excellence of students, the strategy developed is to optimize all programs that have been established and not only rely on superior programs. Curriculum programs, student programs, public relations programs, sarpras programs, to extracurricular programs are follow-ups that must be met, fostered and improved from time to time. (WKM-3, WKS-2).

\section{d. Strategy Selection}

Strategy selection is the final stage and step in implementing strategic planning in improving quality with an insight into excellence, where this stage is carried out after previously carrying out the formulation of the vision and mission, analysis of the internal and external environment as well as analysis of strategy choices and keys to success. The results of the analysis of the Strategic Plan document and the Madrasah Self-Evaluation, the objectives of the MAN 2 Model Medan are compatible and clarify the vision and mission that have been set. Objectives are also seen to reach the results of internal/external environmental assessments and prioritized ones and allow them to be developed in response to strategic issues.

If mapped again, then the target of MAN 2 Model Medan has the scope of improving school management, curriculum development, student development, and infrastructure development. On this basis, determining the strategy is an important component in improving the progress of the madrasa. Strategies can help madrasas develop their existing potential by minimizing threats. The selection of the right strategy will highlight the strengths and cover all the weaknesses of the madrasa. By considering and paying attention to the rate of growth and establishment of similar private madrasas, as well as the increasingly high demands of parents for academic and moral quality, madrasas need to formulate certain strategies so that MAN 2 Model Medan continues to carry out its mission as a "reference" and "model" madrasah. "As mandated by the government through the ministry of religion and madrasas of first choice for the people of North Sumatra.

Based on the results of interviews with the madrasa committee, which is a representative of student guardians, researchers know that one of the factors of interest for student guardians to send their sons and daughters to send their sons and daughters to MAN 2 Model Medan is because the madrasa environment is Islamic, beautiful, has excellent programs, has quite a lot of achievements. 
Alumni are widely accepted to PTN or PTKIN through invitations and regular channels. Most importantly, this madrasa familiarizes children with the application of Islamic character, excels in achievement, has a global perspective, loves the environment, and loves the environment the homeland.

\section{Organizing strategic plans for quality improvement with an insight into excellence at StateMadrasah Aliyah}

Madrasah Aliyah Negeri 2 Model Medan as an organization is a place where people gather who work together to achieve goals. As an organization in an effort to improve the quality of insightful excellence in its organization, it involves all elements in the madrasa to make it happen. Related to this the results of interviews with the Head of Madrasah in one interview opportunity are as follows:

Quality madrasas can only be realized by involving all elements or madrasa residents, it is impossible to rely solely on me as the head of the madrasa, nor can I just command or delegate it to subordinates such as the deputy head or teacher. To realize the plan that has been prepared previously, the next step is to determine who has to carry it out, for this we make a work team for each field of work that I want to carry out which I put in the form of an implementation decision letter based on the field that is responsible for the teacher or employee who considered biased and able to make it happen. (KM).

The results of the search for documentation carried out in the field showed that there were various decrees signed by the head of the madrasa among the strategic planning team chaired by $\mathrm{RH}$ complete with the composition of the fields or elements, the Decree of the Superintendent of the flagship program and other things.

\section{Implementation of strategic plans in improving quality with an insight into excellence in State Madrasah Aliyah}

The results of the analysis of the internal and external environment that are equipped with a SWOT analysis and analysis of strategy choices and keys to success, the selection of quality improvement strategies with an insight into excellence at MAN 2 Model Medan includes improving processes on an ongoing basis, setting quality assurance strategies and quality standards, creating a school culture or culture, make organizational changes and maintain relationships with stakeholders, both the central, regional and community governments. This strategy was then sharpened by researchers through a series of interviews, document searches and observations in order to get a more detailed picture related to the implementation of strategic plans in improving the quality of insight into excellence in MAN 2 Model Medan.

\section{a. Continuously improve processes}

The implementation of madrasa policies in improving the quality of insight into excellence at MAN 2 Model Medan is carried out by carrying out continuous improvements to the overall performance of madrasas, which should be used as a permanent goal of the organization. The continuous process is the basic principle in which quality is the center. This process is complementary and brings to life the principle of process orientation and the principle of focus on the fulfilment of desires and the level of satisfaction of the users.

In this regard, the results of the interview with the deputy head of the madrasa in the field of curriculum through one interview opportunity stated the following:

Regarding the implementation of the policy of improving the quality of insight into excellence at MAN 2 Model Medan through continuous process improvements carried out by improving the formulation of the vision, mission and goals of the madrasa, improving the madrasa administration system in the form of the availability of the number of learning arrangements, the person in charge of the existing program and making standard procedures and improving the quality of 
human resources where the efforts include providing training, teacher supervision, improving teacher qualifications, comparative studies, inviting leaders and organizing learning innovations. (WKM-1).

The same expression was also expressed by one of the teachers in an interview as follows:

We are used to making improvements from time to time, these improvements are intended to maximize learning. Related to quality and professional improvement by sending and participating in training or workshops, teacher supervision, teacher qualification improvement, comparative studies, inviting leaders (GR).

Based on the description above, it can be concluded that the implementation of the policy of improving the quality of insight into excellence at MAN 2 Model Medan in the aspect of continuous process improvement is carried out by 1) improving the formulation of the vision, mission and objectives of the madrasa, 2) improving the madrasa administration system in the form of the availability of the number of learning implementations. This is in charge of existing programs and makes standard procedures, and 3) improving the quality of human resources where efforts include providing training, teacher supervision, improving teacher qualifications, comparative studies, inviting leaders and organizing learning innovations.

\section{b. Establish a quality assurance strategy and quality standards}

The implementation of madrasa policies in improving the quality of insight into excellence in MAN 2 Model Medan is carried out by establishing a quality assurance strategy and quality standards. In this regard, the results of interviews with the head of the madrasa are stated as follows:

The quality assurance strategy and quality standards that have been implemented so far have begun by providing quality assurance and quality standards for madrasas which are operationally realized by establishing a quality action plan which I as the head of the madrasa conveyed at the beginning of the semester through teacher council meetings, quality improvement programs and madrasa quality assurance (KM).

The results of an interview with one of the homeroom teachers and also a teacher obtained the following responses:

The teacher council meeting which took place at the beginning of the semester and was attended by all teachers became an opportunity for the head of the madrasa to convey the entire program, implementation provisions, problems faced and including strategies in implementing the program and its quality assurance. He conveyed that in order to achieve the goals and objectives of the program, it is hoped that the readiness of the institution in realizing quality includes cooperation, leadership, communication, advice and supporting infrastructure. (WKS and GR).

The chairman of the committee also provided additional information related to quality assurance efforts and quality standards at MAN 2 Model Medan as follows:

This involvement in determining quality assurance and standards usually takes place through an official meeting at the beginning of the semester, on this occasion the head of the madrasa usually conveys various programs, goals and objectives to be achieved and is related to us, the madrasa head usually asks for assistance related to the preparation of the madrasah income and expenditure budget to support the program and the achievement of the objectives to be achieved (KMT).

The description above confirms that it can be concluded that the implementation of the policy of improving the quality of insight into excellence in MAN 2 Model Medan is on the strategy of quality assurance and quality standards. Regarding the operational aspects, it is realized by: 1) establishing 
a quality action plan, 2) quality improvement programs and quality assurance for madrasah, 3) the readiness of the institution in realizing quality which includes cooperation, leadership, communication, supporting facilities and infrastructure as well as the preparation of a revenue budget. And madrasah spending to support the program and achieve the goals to be achieved.

\section{c. Creating a culture or madrasa culture}

Education as a whole is a process of cultural transformation from educators to students. This process is very effective in passing on a quality culture in madrasas. Related to this, the results of an interview with one of the homeroom teachers obtained the following responses:

We are all aware that the educational process that we carry out is able to shape the culture of the students, including the culture of quality through the transformation of positive values. The method of forming a culture in improving student learning achievement is made by a team consisting of the head of the madrasa, the deputy head of the madrasa and representatives of the teachers who are the organizers of the flagship program. This madrasa culture was developed and disseminated to all madrasa human resources at the beginning of the semester. The school madrasa culture and culture that is developed to support the improvement of student achievement is carried out through timely attendance, Duhuha prayer, reading the Qur'an and holding donations every Friday and other donations in the form of the death of students and parents of students. $(W K S-5)$.

In the education process, educating is a human civilizing process. Madrasas are formal institutions that are the centre for civilizing humans by transforming values to students so that cultural values can develop properly. Related to the quality culture developed to foster teachers, employees and students who are socialized at the beginning of the semester, several school madrasa cultures and cultures are developed to support the improvement of student achievement through timely attendance, Duhuha prayer, reading the Qur'an and holding infaq every year. Friday and other infaq in the form of the death of students and parents of students.

\section{d. Making organizational changes}

Organizational change is a process by which the madrasah moves from its current state to the desired future to increase its organizational effectiveness. Related to this, MAN 2 Model Medan continuously continues to make changes from time to time in order to find the ideal formation of madrasa administration and related to this, it is represented by an organizational structure that contains the authority, duties and functions of organizational units starting from the head of the madrasa to the smallest element.

e. Maintaining relationships with stakeholders, both central government, regional and community.

The results of this research interview found that there were five efforts on the part of the madrasa in maintaining relationships with stakeholders, both central, regional and community including: 1) Giving rewards to teachers, 2) giving rewards to students, 3) Home visits for students, 4) WatsApp Group, and 5) Meeting with parents.

\section{Evaluation of strategic plans in improving quality with an insight into excellence in State Madrasah Aliyah}

To find out the success of planning, organizing, and implementing strategic plans, the evaluation must be carried out. The evaluation process is the last stage of a series of strategic management processes. The strategic evaluation of improving the quality of education at MAN 2 Model Medan is carried out in stages. The results of interviews with the principal of the madrasa obtained the following responses: 
The evaluation of the quality improvement program with the perspective of excellence in Madrasah Aliyah Negeri 2 Model Medan is carried out through the stages and steps of monitoring all the results of planning and implementation, measuring the performance of individuals and madrasa institutions, compiling reports on the implementation of activities and taking corrective steps (KM).

Based on the information above, it can be stated that the evaluation of the strategic plan in an effort to improve the quality with an insight of excellence in Madrasah Aliyah Negeri 2 Model Medan is carried out through the stages and steps of monitoring all the results of the plan and implementation, measuring the performance of individuals and institutions, compiling reports on the implementation of activities and taking corrective steps.

\section{CONCLUSION}

Strategic planning is carried out by deliberation and cooperation to formulate the vision and mission of the madrasa, an analysis of the internal and external environment, the key to success and strategy selection, and strategic planning. A strategic organisation is carried out by establishing work teams and decrees and teachers and employees who are considered capable of implementing the strategic plan. Quality assurance and quality standards are established for quality improvement, establishing a madrasa culture or culture, making organizational changes, and maintaining good relations with stakeholders, both the central government and the area and community, in order to implement plans and policies. As a result, the strategic plan's evaluation is carried out sequentially: first, it is monitored, then it is measured, then it is compiled, and finally, it is taken corrective actions.

\section{REFERENCES}

Abdulraheem, B. I., Olapipo, A. R., \& Amodu, M. O. (2012). Primary health care services in Nigeria: Critical issues and strategies for enhancing the use by the rural communities. Journal of public health and epidemiology, 4(1), 5-13.

Al Shobaki, M. J., Naser, S. S. A., Amuna, Y. M. A., \& El Talla, S. A. (2017). Impact of electronic human resources management on the development of electronic educational services in the universities. International Journal of Engineering and Information Systems, 1(1), 1-19.

Aremu, M. A., \& Oyinloye, O. O. (2014). Relationship Between Strategic Management And Firms'performance In Nigerian Banking Industry. Kuwait Chapter of the Arabian Journal of Business and Management Review, 4(3), 28.

Aziz, S., Mahmood, M., \& Rehman, Z. (2018). Implementation of CIPP Model for Quality Evaluation at School Level: A Case Study. Journal of Education and Educational Development, 5(1), 189206.

Dewi, R. (2013). Kinerja Kepala Sekolah: Pengaruh kepemimpinan Transformasional, konflik dan efikasi diri. Jurnal Ilmu Pendidikan, 18(2).

Fauzi, I. (2020). Melacak Praktik Manajemen Strategik pada Persekolahan Usia Dini: Kajian di TKRA Asy Syafi'iyah Baruga, Kendari. Shautut Tarbiyah, 24(2), 239-262.

Firdaus, N.M., \& Ansori, A. (2019). Optimizing Management of Early Childhood Education in Community Empowerment. Journal of Nonformal Education, 5(1), 89-96.

Hanun, F. (2015). Akreditasi Madrasah Sebagai Kunci Keberhasilan dalam Pemenuhan Standar Nasional Pendidikan (SNP). EDUKASI: Jurnal Penelitian Pendidikan Agama dan Keagamaan, 13(1).

Irmayani, H., Wardiah, D., \& Kristiawan, M. (2018). The strategy of SD Pusri in improving educational quality. International Journal of Scientific \& Technology Research, 7(7), 113-121.

Kheroni, A. (2020). Implementasi Manajemen Strategik Pada Lembaga Pendidikan Majelis Taklim Darunnajah Desa Bejiruyung Kecamatan Sempor Kabupaten Kebumen. Cakrawala: Jurnal Manajemen Pendidikan Islam dan studi sosial, 4(2), 79-104.

Mubarok, A. A., Uswatiyah, W., Wasiman, I., \& Supyan, U. (2021). Balanced Score Card (BSC) dan Kembalian Pendidikan. Reslaj: Religion Education Social Laa Roiba Journal, 3(3), 378-387.

Mukhtar, H., \& Prasetyo, M. A. M. (2020). Pesantren Efektif Model Teori Integratif Kepemimpinan-Komunikasi-Konflik Organisasi. Deepublish. 
Mustiali, M. (2021). Implementasi Model "Samarasa" sebagai Kunci Keberhasilan dalam Mengelola Sekolah. NIZĀAMULILMI: Jurnal Manajemen Pendidikan Islam, 6(1), 1-10.

Ramazani, J., \& Jergeas, G. (2015). Project managers and the journey from good to great: The benefits of investment in project management training and education. International Journal of Project Management, 33(1), 41-52.

Saleh, K. (2014). Kepemimpinan Kepala Sekolah dalam Meningkatkan Kualitas Pendidikan. FENOMENA, 6(1).

Simon, D., Fischbach, K., \& Schoder, D. (2014). Enterprise architecture management and its role in corporate strategic management. Information Systems and e-Business Management, 12(1), 542.

Supriadi, A. (2012). Analisis Prakondisi Implementasi Kebijakan Peningkatan Kompetensi Guru. Jurnal Pendidikan Dan Pembelajaran (JPP), 18(1), 36-46.

Wani, I. A., \& Mehraj, H. K. (2014). Total quality management in education: An analysis. International Journal of Humanities and Social Science Invention, 3(6), 71-78. 